\title{
Use of Molecular Methods in Identification of Candida Species and Evaluation of Fluconazole Resistance
}

\author{
Meltem Yalinay Cirak ${ }^{+}$, Ayse Kalkanci, Semra Kustimur \\ Department of Medical Microbiology, Faculty of Medicine, Gazi University, Besevler, Ankara, Turkey
}

\begin{abstract}
The aim of this study was to evaluate the use of one of the molecular typing methods such as PCR (polymerase chain reaction) following by RFLP (restriction fragment length polymorphism) analysis in the identification of Candida species and then to differentiate the identified azole susceptible and resistant Candida albicans strains by using AP-PCR (arbitrarily primed-polymerase chain reaction). The identification of Candida species by PCR and RFLP analysis was based on the size and primary structural variation of rDNA intergenic spacer regions (ITS). Forty-four clinical Candida isolates comprising 5 species were included to the study. The amplification products were digested individually with 3 different restriction enzymes: HaeIII, DdeI, and BfaI. All the isolates tested yielded the expected band patterns by PCR and RFLP analysis. The results obtained from this study demonstrate that Candida species can be differentiated as $\mathrm{C}$. albicans and non-C. albicans strains only by using HaeIII restriction enzyme and $\mathrm{Bfa}$ I maintains the differentiation of these non-C. albicans species. After identification Candida species with RFLP analysis, C. albicans strains were included to the AP-PCR test. By using AP-PCR, fluconazole susceptible and resistant strains were differentiated. Nine fluconazole susceptible and 24 fluconazole resistant $\mathrm{C}$. albicans were included to the study. Fluconazole resistant strains had more bands when evaluating with the agarose gel electrophoresis but there were no specific discriminatory band patterns to warrant the differentiation of the resistance.

The identification of Candida species with the amplification of intergenic spacer region and RFLP analysis is a practical, short, and a reliable method when comparing to the conventional time-consuming Candida species identification methods. The fluconazole susceptibility testing with AP-PCR seems to be a promising method but further studies must be performed for more specific results.
\end{abstract}

Key words: Candida - restriction fragment length polymorphism (RFLP) analysis - arbitrarily primed polymerase chain reaction (AP-PCR)

Candida species are increasingly important nosocomial pathogens in immunocompromised, Intensive Care Unit and postoperative patients (Dembry et al. 1994). Candida albicans ranks first among the identified species but the proportion of non-C. albicans species seems to be increasing either (Bart-Delabesse et al. 1995, Dib et al. 1996). Hence the accurate identification of Candida to species level is increasingly important. Treatment of Candida infections is generally effective and usually involves the use of topical or systemic antifungal therapy with drugs such as the polyenes and the azoles (Pfaller et al. 1994). Azole antifungal agents have therapeutic activity against different Candida species. Among the azole drugs, fluconazole shows satisfactory tolerance and efficiency. However, in recent years increasing resistance with fluconazole has appeared and antifungal drug resistance is quickly becoming a major problem especially in immunocompromised patients (White et al. 1998, Xu et al. 2000). This resistance also favors the emergence of Candida krusei and Candida glabrata (Bart-Delabesse et al. 1993, Nho et al. 1997).

Financial support: Gazi University, project 01/2000-17 ${ }^{+}$Corresponding author. Fax: +90-312-212.4647. E-mail: meltemyc@gazi.edu.tr

Received 28 February 2003

Accepted 29 October 2003
Conventional methods for the identification of Candida species are based on assimilation, fermentation reactions, and morphology (Williams et al. 1995, Del Castillo et al. 1997). Given the many limitations of phenotyping methods, molecular biology methodology have been adapted for use as molecular identification methods. Recent advances in the use of molecular DNA analysis have facilitated the development of identification systems at a species level (Dembry et al. 1994, Williams et al. 1995, Del Castillo et al. 1997, Diaz-Guerra et al. 1997, Barchiesi et al. 1997, Taylor et al. 1999). Identification of Candida species has been achieved by restriction fragment length polymorphism (RFLP) analysis of the ribosomal DNA (rDNA) repeat of Candida species in previous studies (Dembry et al. 1994, Bart-Delabesse et al. 1995, Williams et al. 1995, Dib et al. 1996, Barchiesi et al. 1997, Taylor et al. 1999).

Molecular biological methods provide biologically relevant information in addition to laboratory identification, such as resistance to antimicrobials (Loeffler et al. 2000). Polymerase chain reaction (PCR) based techniques can be used to distinguish Candida species that may be resistant to fluconazole (Bart-Delabesse et al. 1993). Random amplified polymorphic DNA (RAPD) also known as arbitrarily primed PCR (AP-PCR), has also increased the applicability of PCR for identification of microorganism. The AP-PCR method, firstly described by Williams et al. (1995), is based on PCR amplification of DNA fragments with arbitrary short primers (9 to 10 bases) with a low annealing temperature $\left(36^{\circ} \mathrm{C}\right)$. These short 
primers whose sequences are not directed toward a known genetic size hybridize randomly to genomic sites. If two such sites are located close enough, within a few kilo bases, then the intervening sequences are amplified and can be visualized by gel electrophoresis (Robert et al. 1995, Weber et al. 1997).

The aim of this study is identifying Candida species by using genotyping methods as PCR and RFLP analysis and then differentiating the azole susceptible and resistant C. albicans strains by using AP-PCR.

\section{MATERIALS AND METHODS}

Isolates - In total of 44 candidal clinical isolates from clinical specimens comprising 5 species, which were stored in our culture collection, were included in this study. Thirty-three of these isolates were blood samples, 5 of them were urine samples, 4 of them were vaginal samples, 1 of the clinical isolates was a drainage material from an abscess and the other sample was isolated from aspiration material. C. albicans ATCC 64551, C. albicans ATCC 64569, C. parapsilosis ATCC 22019, C. krusei ATCC 6258, C. glabrata ATCC 90030 reference strains were also included to the study. Clinical isolates were identified by using ID32 C (API system; bioMérieux, Marcy l'Etoile, France) kit, according to their biochemical features.

Antifungal susceptibility testing - The minimum inhibitory concentrations of fluconazole for all isolates were determined by broth microdilution assays for yeasts according to the National Committee for Clinical Laboratory Standards (NCCLS) guidelines (NCCLS 1997).

DNA extraction - Fungi were grown on Sabouraud Dextrose Agar for $48 \mathrm{~h}$ at $30^{\circ} \mathrm{C}$ and suspended in sterile $0.9 \% \mathrm{NaCl}$ solution at a concentration of $10^{6} \mathrm{CFU} / \mathrm{ml}$ (McFarland 0.5 corresponds to $10^{6}$ cells). DNA was extracted as described previously with some modifications (Pearce \& Howell 1991, Robert et al. 1995). For the extraction of whole-cell DNA, yeast suspensions were incubated with lysis buffer containing $0.1 \mathrm{mg} / \mathrm{ml}$ proteinase $\mathrm{K}, 150 \mathrm{mM} \mathrm{NaCl}, 25 \mathrm{mM}$ EDTA, $10 \mathrm{mM}$ Tris$\mathrm{HCl}(\mathrm{pH} 8.0), 0.5 \% \mathrm{SDS}$ for $3 \mathrm{~h}$ at $55^{\circ} \mathrm{C}$. After the phenolchloroform extraction, pellet was kept overnight at $-20^{\circ} \mathrm{C}$ in $95 \%$ ethanol with sodium acetate. The supernatant was discarded, and the pellet was allowed to dry. DNA was then dissolved in $50 \mu \mathrm{l}$ of sterile water and $5 \mu \mathrm{l}$ of DNA solution was used for amplification procedure.

PCR - The PCR designed by Williams et al. (1995) was used to amplify intergenic spacer regions (ITS) of ribosomal DNA (rDNA) with the primers ITS1 (5' -TCC GTA GGT GAA CGT GCG G-3') and ITS4 (5' -TCC TCC GCT TAT TGA TAT GC-3'). For the optimum PCR conditions, a reaction volume of $100 \mu \mathrm{l}$ contained $0.2 \mathrm{mM}$ each deoxynucleoside triphosphate, $1.5 \mathrm{mM}$ magnesium chloride, $0.5 \mu \mathrm{M}$ each primer, $10 \mathrm{x}$ Taq buffer and $2.5 \mathrm{U}$ of Taq polymerase (DNAmp, England) and $0.5 \mu \mathrm{g}$ of candidal DNA as template were used. Negative controls were performed with sterile deionised water in place of the template DNA. Reaction mixtures were subjected to 35 cycles of the following incubations: denaturation at $95^{\circ} \mathrm{C}$ for $1 \mathrm{~min}$, primer annealing at $55^{\circ} \mathrm{C}$ for $1 \mathrm{~min}$ and extension at $72^{\circ} \mathrm{C}$ for $2 \mathrm{~min}$ (Williams et al. 1995). A Hybaid thermal cycler was used for the PCR reactions (Hybaid Corp.,
Cambridge, UK). Ten $\mu$ from the amplicons were analyzed in $2 \%$ agarose gel with $1 \times$ TBE buffer stained with ethidium bromide and visualized by illumination with UV light.

Typing by RFLP - PCR products were digested individually with $10 \mathrm{U}$ of restriction enzymes HaeIII, BfaI, and DdeI (New England Biolabs, Hitchin, UK) by overnight incubation at $37^{\circ} \mathrm{C}$. The resulting restriction fragments were analysed by agarose gel electrophoresis using $3 \%$ 3:1 NuSieve agarose (FMC BioProducts, Kent, UK) gels in 1x Tris-phoshate-EDTA buffer (Williams et al. 1995, Nho et al. 1997).

$A P-P C R$ - Five DNA specimens extracted from $C$. albicans strains were used in the preliminary studies and oligonucleotides containing below $50 \%$ G-C contents were tested for primary screening of isolates (data not shown). Fourteen different primers were tested and because the primer (5'-AAA TGA AGG GGG TGT CGT T-3') was evaluated as the most differentiating one, it was used in the following experiments. Nine fluconazole susceptible and 24 fluconazole resistant $C$. albicans were included to the study. Twenty-four fluconazole resistant strains from our culture collection were especially enrolled to this study. PCR was carried out with about 50 pmol from each of the primers, $2.5 \mathrm{mM} \mathrm{MgCl}_{2}, 200 \mu \mathrm{M}$ from each of the 4 deoxynucleoside triphosphates, 1 U Taq-DNA polymerase (DNAmp, England), 50 mM KCL, 10 mM Tris-HCL (pH 8.3 ), and $5 \mu \mathrm{l}$ of the extracted DNA in $50 \mu \mathrm{l}$ volume of total mixture.

Amplification was performed in Hybaid Sprint 'thermal cycler' following temperatures; $95^{\circ} \mathrm{C}$ for $5 \mathrm{~min}, 94^{\circ} \mathrm{C}$ for 30 $\mathrm{s}, 30^{\circ} \mathrm{C}$ for $50 \mathrm{~s}, 72^{\circ} \mathrm{C}$ for $1 \mathrm{~min}$ for 15 cycles, followed by $94^{\circ} \mathrm{C}$ for $20 \mathrm{~s}, 55^{\circ} \mathrm{C}$ for $45 \mathrm{~s}, 72^{\circ} \mathrm{C}$ for $1 \mathrm{~min}$ for 30 cycles and finally $72^{\circ} \mathrm{C}$ for $5 \mathrm{~min}$. Ten $\mu \mathrm{l}$ from the amplicons were analyzed in $2 \%$ agarose gel with $1 \mathrm{x}$ TBE buffer stained with ethidium bromide and visualized by illumination with UV light.

\section{RESULTS}

Thirty-four C. albicans, 3 C. parapsilosis, 2 C. krusei, 4 C. glabrata, 1 C. rugosa strains were identified by ID32 $\mathrm{C}$ kit. The origin of the identified clinical isolates was shown in detail in Table I. The intergenic spacer region was successfully amplified from all tested isolates, and a distinct product size was obtained for all isolates of a given species. All isolates yielding a product size of approximately 800 bp identified as C. glabrata and an isolate with a product size of approximately $500 \mathrm{bp}$ identified as $C$. rugosa can be differentiated only by the size of their PCR products. A product of approximately $520 \mathrm{bp}$ was obtained from the remaining isolates.

These isolates were studied further by RFLP analysis following digestion of the PCR products by the restriction enzymes HaeIII, BfaI, and DdeI. The size of the fragments obtained from the products of restriction enzymes was shown in Table II. Fig. 1a shows a gel electrophoresis of PCR products obtained from Candida ATCC strains partly digested by HaeIII restriction enzyme. Figs $1 \mathrm{~b}$ and $1 \mathrm{c}$ show PCR products obtained from Candida clinical isolates digested by HaeIII restriction enzyme. Fig. 2 demonstrates the restriction digestion of PCR products with the enzyme DdeI and Fig. 3 demonstrates products 
TABLE I

The origin of the identified clinical isolates

\begin{tabular}{|c|c|c|}
\hline Number & $\begin{array}{l}\text { Species of } \\
\text { Candida isolates }\end{array}$ & $\begin{array}{l}\text { Source of } \\
\text { Candida isolates }\end{array}$ \\
\hline 1 & C. parapsilosis & Blood \\
\hline 2 & C. krusei & Vagen \\
\hline 3 & C. albicans & Blood \\
\hline 4 & C. albicans & Blood \\
\hline 5 & C. albicans & Blood \\
\hline 6 & C. albicans & Blood \\
\hline 7 & C. parapsilosis & Blood \\
\hline 8 & C. albicans & Blood \\
\hline 9 & C. albicans & Blood \\
\hline 10 & C. albicans & Blood \\
\hline 11 & C. albicans & Blood \\
\hline 12 & C. albicans & Blood \\
\hline 13 & C. albicans & Blood \\
\hline 14 & C. albicans & Blood \\
\hline 15 & C. albicans & Blood \\
\hline 16 & C. albicans & Blood \\
\hline 17 & C. albicans & Blood \\
\hline 18 & C. glabrata & Blood \\
\hline 19 & C. albicans & Blood \\
\hline 20 & C. albicans & Blood \\
\hline 21 & C. albicans & Blood \\
\hline 22 & C. albicans & Blood \\
\hline 23 & C. albicans & Blood \\
\hline 24 & C. albicans & Blood \\
\hline 25 & C. albicans & Blood \\
\hline 26 & C. albicans & Blood \\
\hline 27 & C. albicans & Blood \\
\hline 28 & C. albicans & Blood \\
\hline 29 & C. albicans & Blood \\
\hline 30 & C. albicans & Blood \\
\hline 31 & C. albicans & Blood \\
\hline 32 & C. albicans & Blood \\
\hline 33 & C. albicans & Blood \\
\hline 34 & C. albicans & Blood \\
\hline 35 & C. glabrata & Urine \\
\hline 36 & C. glabrata & Urine \\
\hline 37 & C. glabrata & Urine \\
\hline 38 & C. albicans & Abscess \\
\hline 39 & C. rugosa & Urine \\
\hline 40 & C.krusei & Vagen \\
\hline 41 & C.parapsilosis & Vagen \\
\hline 42 & C. albicans & Aspiration material \\
\hline 43 & C. albicans & Vagen \\
\hline 44 & C. albicans & Urine \\
\hline
\end{tabular}

related to the digestion with enzyme $B f a \mathrm{I}$.

All of the studied isolates were found to yield the expected band patterns. RFLP analysis of the PCR products of the isolates demonstrated that HaeIII was the most differentiating enzyme among the others. As $C$. parapsilosis and C. krusei had similar restriction products, they could not be differentiated only by HaeIII. C. krusei could be differentiated by $B f a I$ digestion. DdeI digestion was used to confirm the $C$. albicans species. All of the $C$. albicans species yielded 100 and approximately $400 \mathrm{bp}$ products with $D d e I$ restriction.

Fig. 4 shows the results of AP-PCR. According to the results of AP-PCR the resistant strains had more than 10
TABLE II

Size of the fragments obtained from the products of restriction enzymes

\begin{tabular}{llll}
\hline & Bfa I & HaeIII & DdeI \\
\hline Candida albicans & - & 90,430 & 100,420 \\
Candida parapsilosis & - & $40,110,390$ & - \\
Candida krusei & 120,200 & $40,90,380$ & - \\
Candida glabrata & - & 200,650 & - \\
\hline
\end{tabular}

The data related to the digestion of $C$. rugosa could not be reached.
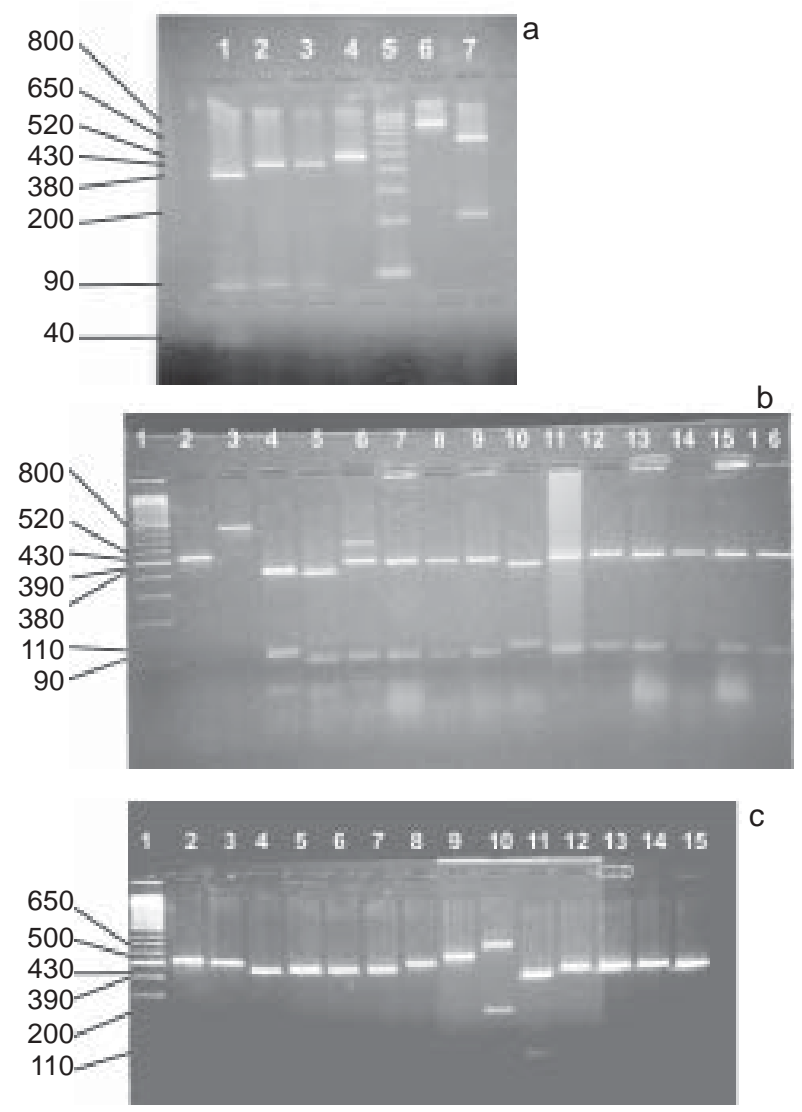

Fig. 1a: restriction digestion of polymerase chain reaction products of Candida ATCC strains with the enzyme HaeIII. Lanes - 1: C. krusei ATCC 6258; 2: C. albicans ATCC 64551; 3: C. albicans ATCC 64569; 4: C. krusei ATCC 6258 (uncut); 5: molecular weight marker (100-1000 bp); 6: C. glabrata ATCC 90030 (uncut); 7: C. glabrata ATCC 90030; 1b: restriction digestion of PCR products of Candida clinical isolates with the enzyme HaeIII. Lanes - 1: molecular weight marker (100-1000 bp); 2: C. albicans (uncut); 3: C. glabrata (uncut); 4: C. parapsilosis; 5: C. krusei; 6-9: C. albicans; 10: C. parapsilosis; 11-16: C. albicans; 1c: restriction digestion of PCR products of Candida clinical isolates with the enzyme HaeIII. Lanes - 1: molecular weight marker (100-1000 bp); 2: C. albicans (uncut); 3: C. krusei; 4-8: C. albicans; 9: C. rugosa (uncut); 10: $C$. glabrata; 11: C. parapsilosis; 12-15: C. albicans

band patterns when evaluating with the agarose gel electrophoresis but there were no specific discriminatory band patterns to warrant the differentiation of the resistance.

RFLP profiles of the strains were analyzed by using PHYLIP phylogenetic analysis program (PHYLIP 


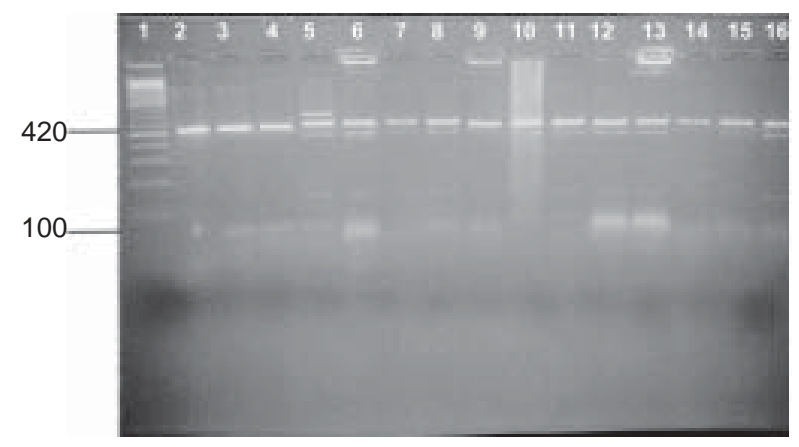

Fig. 2: restriction digestion of polymerase chain reaction products of Candida clinical isolates with the enzyme DdeI. Lanes - 1: molecular weight marker (100-1000 bp); 2: C. albicans; 3: C. parapsilosis 4: C. krusei; 5-8: C. albicans; 9: C. glabrata; 10-16. C. albicans

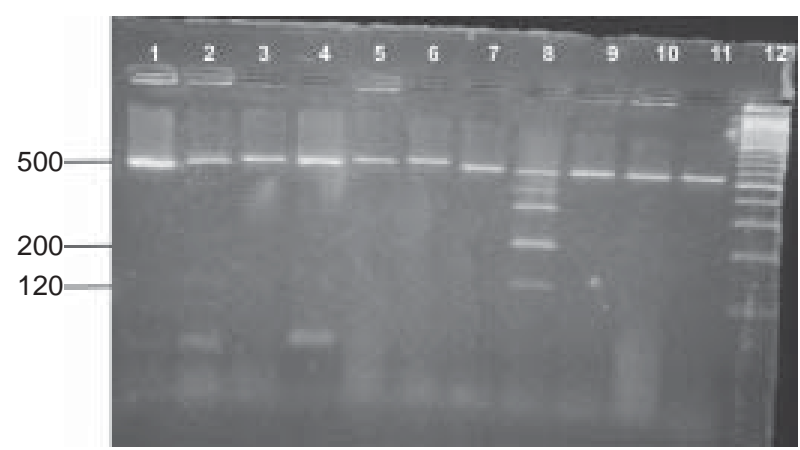

Fig. 3: restriction digestion of polymerase chain reaction products of Candida clinical isolates with the enzyme BfaI. Lanes - 1: C. parapsilosis; 2: C. glabrata; 3-4: C. parapsilosis; 5-6: C. albicans; 7: C. rugosa; 8: C. krusei; 9-11: C. albicans; 12: molecular weight marker (100-1000 bp)

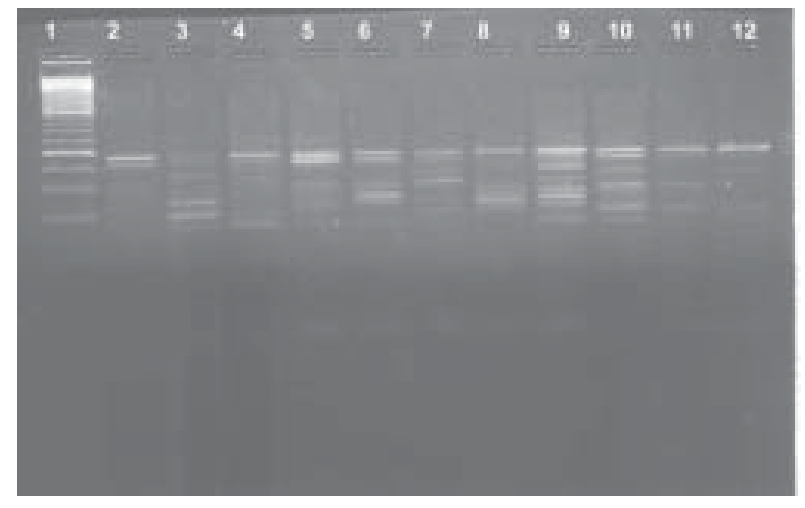

Fig. 4: the results of arbitrarily primed polymerase chain reaction Lanes - 1: molecular weight marker (100-1000 bp); 2-5: fluconazole susceptible $C$. albicans strains; 6-12: fluconazole resistant $C$. albicans strains

phylogeny inference package, version $3.5 \mathrm{c}$, by Joseph Felstein, University of Washington, Seattle, 1993) and were demonstrated as a dendogram in Fig. 5.

\section{DISCUSSION}

Identification of pathogenic fungi has changed dramatically over the past decade through direct examination of the tremendous variation present in DNA
(McEwen et al. 2000). Typing methods based on phenotypic characteristics are usually cheap and easy to perform but they have shown a lack in their reproducibility. On the contrary, genotypic methods are expensive and require sophisticated technology but they usually have good reproducibility (Del Castillo et al. 1997).

RFLP is based on the digestion of DNA. Every organism possesses unique nucleotide sequences that distinguish it from every other organism on the basis of the number and size of the fragments. DNA is extracted from isolates and cleaved into fragments by restriction endonucleases, the fragments are separated by gel electrophoresis (Dembry et al. 1994, Taylor et al. 1999). RFLP requires only a moderate of time and work, the method has been used for genotyping a variety of pathogens within the last few years (Taylor et al. 1999).

RFLP method used in this study has been successfully applied for the exact identification of these 5 species. All the species were examined by the RFLP method have proved to be reasonably homogeneous internally and quite distinct from other species. The differences in the restriction patterns for the rDNA regions of the various Candida species serve as a rapid means of differentiating among these organisms. A HaeIII digest is definitive for distinguishing $C$. albicans species from other non- $C$. albicans species. $B f a \mathrm{I}$ is found to be useful in the differentiation of C. parapsilosis and C. krusei. DdeI digestion also seems to be efficient to identify $C$. albicans species.

Our identification of samples, based on RFLP with HaeIII, BfaI, and DdeI is similar to those previous investigators. Williams et al. (1995) demonstrated that not only C. glabrata but also C. guilliermondii and $C$. pseudotropicalis could be discriminated on the basis of PCR product size alone. The results of $B f a$ I digestion are found to be very similar for the differentiation of $C$. parapsilosis and C. krusei. DdeI restriction enzyme could allow the identification of $C$. albicans species and if necessary $C$. tropicalis species as mentioned before (Williams et al. 1995).

Fluconazole is a potent antifungal antibiotic that perturbs the biosynthesis of ergosterol by blocking an alpha-14-demethylation step in the pathway. Fluconazole is currently the most widely used antifungal drug because it can be given orally, lacks major side effects, and has broad efficacy against most pathogenic yeasts, including C. albicans. Therefore, fluconazole-resistant fungal pathogens and the detection of the resistance are very important (Xu et al. 2000). There are several known mechanisms of azole resistance in Candida species, including point mutations in the gene ERG11, which encodes the target enzyme of the azoles, $14-\alpha$-demethylase (Loeffler et al. 2000), reduced azole membrane permeability, and, more speculative, an overproduction of p-450 (van Belkum 1994, White et al. 1998). Genetic typing of fungal strains could demonstrate variability as a response to fungistatic treatment and as such could be useful for appropriate drug application (Pfaller et al. 1994, van Belkum 1994).

AP-PCR methodology seems to be a promising method to detect fluconazole resistance in Candida species 


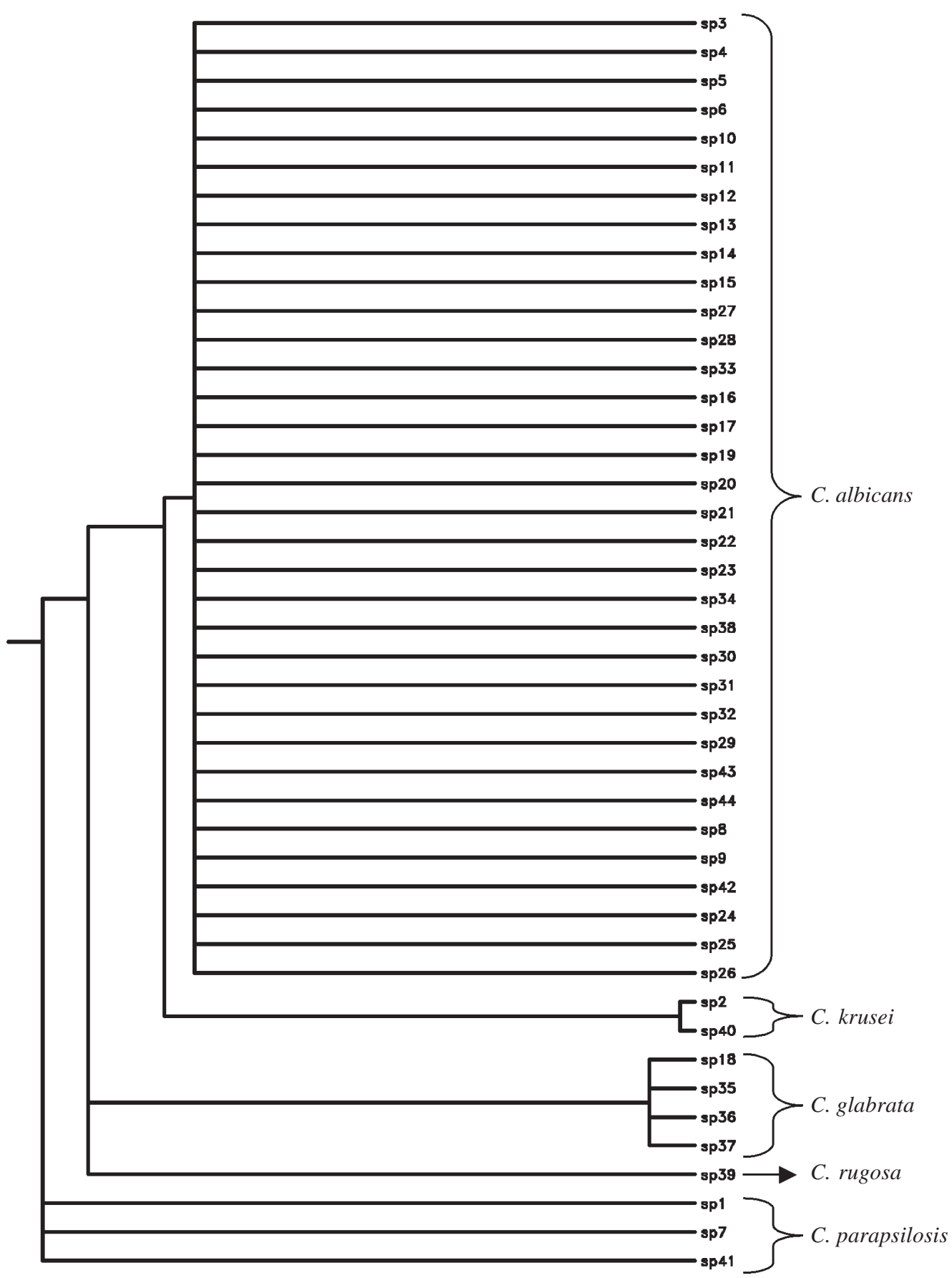

Fig. 5: dendogram of restriction fragment length polymorphism profiles (PHYLIP version 3.5c) of candidal clinical isolates using HaeIII, $B f a I$, and DdeI enzymes; C.: Candida

rapidly and simply early in the disease process but further studies must be performed for more specific results. If this methodology could be available, this capacity should enable the clinician to use the most appropriate antifungal agent early enough to possibly affect the mortality and morbidity resulting from fungal infections.

In this present study, genotyping of Candida species was performed by using RFLP analysis following the amplification of ITS region. The results obtained from this study demonstrate that by using merely the restriction enzyme HaeIII the differentiation of C. albicans and nonC. albicans strains can be performed easily and the further analysis by $B f a I$ restriction enzyme allows the identification of $C$. parapsilosis and C. krusei. After this identification the fluconazole resistance of $C$. albicans strains has been detected by using AP-PCR. Analysis of RFLPs derived from the DNA of Candida species has the advantage of being easy, rapid, and reliable when compared with the phenotypic methods which insensitive, lacked reproducibility and standardization are besides have lim- 
ited availability. AP-PCR appears to be a promising typing method for the detection of resistance, but more specific and further studies must be performed in order to develop this amplification method for the usage of fluconazole resistance detection.

\section{REFERENCES}

Barchiesi F, Falconi Di Francesco L, Compagnucci P, Arzeni D, Cirioni O, Scalise G 1997. Genotypic identification of sequential Candida albicans isolates from AIDS patients by polymerase chain reaction techniques. Eur J Clin Microbiol Infect Dis 16: 601-605.

Bart-Delabesse E, Boiron P, Carlotti A, Dupont B 1993. Candida albicans genotyping in studies with AIDS developing resistance to fluconazole. J Clin Microbiol 35: 2933-2937.

Bart-Delabesse E, van Deventer H, Goesse W, Poirot J, Lioret N, Van Belkum A, Dromer F 1995. Contribution of molecular typing methods and antifungal susceptibility testing to the study of a candidemia cluster in a burn care unit. J Clin Microbiol 33: 3278-3283.

Del Castillo L, Bikandi J, Nieto A, Quindós G, Sentandreu R, Pontón J 1997. Comparison of morphotypic and genotypic methods for strain delineation in Candida. Mycoses 40: 445-450.

Dembry LM, Vazquez JA, Zervos MJ 1994. DNA analysis in the study of epidemiology of nosocomial candidiasis. Infect Control Hosp Epidemiol 15: 48-53.

Diaz-Guerra TM, Martinez-Suarez JV, Laguna F, RodriguezTudela JL 1997. Comparison of four molecular typing methods for evaluating genetic diversity among Candida albicans isolates from human immunodeficiency viruspositive patients with oral candidiasis. J Clin Microbiol 35: 856-861.

Dib JC, Dube M, Kelly C, Rinaldi MG, Patterson JA 1996. Evaluation of pulse-field gel electrophoresis as a typing system for Candida rugosa: comparison of karyotype and restriction fragment length polymorphisms. J Clin Microbiol 34: 1494-1496.

Loeffler J, Hagmeyer L, Hebart H, Henke N, Schumacher U, Einsele H 2000. Rapid detection of point mutations by fluorescence resonance energy transfer and probe melting curves in Candida species. Clin Chem 46: 631-635.

McEwen JG, Taylor JW, Carter D, Xu J, Felipe MS, Vilgalys
R, Mitchell TG, Kasuga T, White T, Bui T, Soares CM 2000. Molecular typing of pathogenic fungi. Med Mycol (Suppl.) 38: 189-197.

NCCLS 1997. Reference method for broth dilution antifungal susceptibility testing of yeasts. Approved Standard. NCCLS document M27-A, Wayne, PA.

Nho S, Anderson MJ, Moore CB, Denning DW 1997. Species differentiation by internally transcribed spacer PCR and HhaI digestion of fluconazole-resistant Candida krusei, Candida inconspicua, and Candida norvegensis strains. J Clin Microbiol 35: 1036-1039.

Pearce MA, Howell SA 1991. Restriction fragment length polymorphism analysis of azole-resistant and azole-susceptible Candida albicans strains. J Clin Microbiol 29: 1364-1367.

Pfaller MA, Rhine-Chalberg J, Redding SW 1994. Variations in fluconazole susceptibility and electrophoretic karyotype among oral isolates of Candida albicans from patients with AIDS and oral candidiasis. J Clin Microbiol 32: 59-64.

Robert F, Lebreton F, Bougnoux ME, Paugam A, Wasssermann D, Schlotterrer M, Tourte-Schaefer C, Dupouy-Camet J 1995. Use of random amplified polymorphic DNA as a typing method for Candida albicans in epidemiological surveillance of a burn unit. J Clin Microbiol 33: 2366-2371.

Taylor JW, Geiser DM, Burt A, Koufopanou V 1999. The evolutionary biology and population genetics underlying fungal strain typing. Clin Microbiol Rev 12: 126-146.

van Belkum A, Melchers W, de Pauw BE, Scherer S, Quint W, Meis JF 1994. Genotypic characterization of sequential Candida albicans isolates from fluconazole-treated neutropenic patients. J Infect Dis 169: 1062-1070.

Weber S, Pfaller MA, Herwaldt LA 1997. Role of molecular epidemiology in infection control. Infect Dis Clin North Am 11: 257-278.

White TC, Marr KA, Bowden RA 1998. Clinical, cellular, and molecular factors that contribute to antifungal drug resistance. Clin Microbiol Rev 11: 382-402.

Williams DW, Wilson MJ, Lewis MAO, Potts AJ 1995. Identification of Candida species by PCR and restriction fragment length polymorphism analysis of intergenic spacer regions of ribosomal DNA. J Clin Microbiol 33: 2476-2479.

Xu J, Ramos AR, Vigalys R, Mitchell TG 2000. Clonal and spontaneous origins of fluconazole resistance in Candida albicans. J Clin Microbiol 38: 1214-1220. 